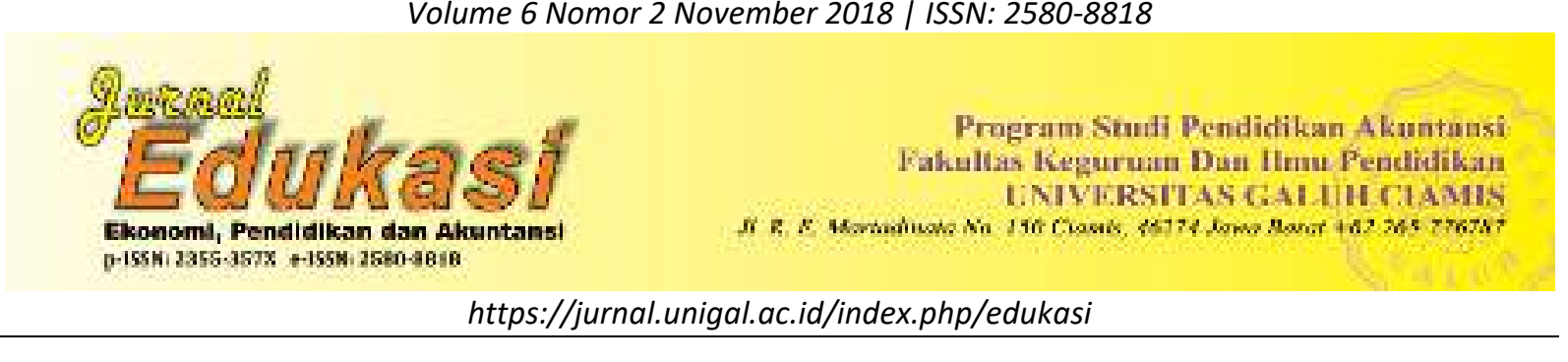

\title{
PENGARUH PENETAPAN COST PURNA JUAL TERHADAP PENDAPATAN NETO PADA UD M'FAMILY TASIKMALAYA
}

\author{
Oleh: \\ Dedeh $^{1}$, Ai Siti Munawaroh ${ }^{2}$ \\ Program Studi Pendidikan Akuntansi Universitas Galuh, Indonesia \\ Email:dedeh.akt15@gmail.com \\ Sejarah Artikel: Diterima September 2018, Disetujui Oktober 2018, Dipublikasikan November 2018
}

\begin{abstract}
ABSTRAK
Masalah dalam penelitian ini adalah (1) Terdapat banyak pelanggan yang tidak melunasi utangnya; (2) Perusahaan merasa rugi karena pengakuan nilai pendapatan yang terealisasi tidak sesuai nilai pendapatan yang diakui; (3) Penetapan biaya pasca penjualan belum diestimasi dengan tepat; (4) Penerapan harga jual yang tidak seimbang jika dibandingkan dengan biaya piutang tak tertagih. Tujuan dari penelitian ini yakni (1) Untuk mengetahui deskripsi penetapan cost purna jual (2) Untuk mengetahui deskripsi perkembangan pendapatan neto (3) Untuk mengetahui pengaruh penetapan cost purna jual terhadap pendapatan neto pada UD M'FAMILY Tasikmalaya. Metode penelitian yang digunakan yaitu metode penelitian deskriptif. Teknik analisis data yang digunakan yaitu uji korelasi product moment dan analisis koefisien determinasi kemudian dilanjutkan dengan pengujian hipotesis digunakan rumus uji t. Hasil penelitian menunjukan bahwa: (1) Penetapan cost purna jual dalam lima tahun terakhir berfluktuatif dalam persentase cenderung mengalami peningkatan. Hal ini disebabkan karena taksiran penetapan cost purna jual selalu berimbang lurus dengan pendapatan neto; (2) Pendapatan neto dalam lima tahun terakhir mngalami peningkatan yang signifikan. Hal ini disebabkan karena perusahaan selalu berupaya untuk meningkatkan omset penjualan, dengan upaya menambah karyawan, memilih pelanggan yang berkontribusi terhadap penciptaan laba perusahaan dan lain-lain;(3) Terdapat pengaruh yang positif dan signifikan penetapan cost purna jual terhadap pendapatan neto, hal ini berarti semakin tepat penetapan cost purna jual maka dapat meningkatkan pendapatan neto.
\end{abstract}

Kata Kunci: Realisasi pendapatan neto, penetapan cost purna jual, penetapan biaya piutang tak tertagih

\section{PENDAHULUAN}

Kebutuhan manusia akan pemuas kebutuhan menyebabkan transaksi penjualan dan pembelian barang dagang yang makin semarak terjadi sehingga melahirkan berbagai system penjualan yang unik dan beragam. Unit bisnis dalam semua lini usaha saat ini berusaha untuk memenuhi kebutuhan para customernya dengan berbagai variasi penjualan dalam upaya optimalisasi laba yang diharapkan.

Seiring dengan perkembangan teknologi dan gaya hidup masyarakat, unit bisnis harus mampu membaca pangsa pasar dengan seksama dan membuka peluang diberbagai usaha. Sistem penjualan kredit guna menarik minat masyarakat dan penguasaan pangsa pasar gencar terjadi, walaupun sistem kredit memiliki resiko yang cukup besar dalam pengakuan pendapatan neto perusahaan karena terdapat kemungkinan adanya piutang tak tertagih. Hal ini menjadi sesuatu yang harus diprediksi dan diatur secara teliti agar harga perolehan pendapatan secara kredit dapat diakui sejumlah nilai wajar pada saat terjadinya transaksi.

Jika ditinjau dari pengakuan pendapatan berdasarkan konsep pembentukan pendapatan yang memiliki dasar upaya dan hasil, dimana hasil atau capaian tidak mungkin terjadi tanpa adanya suatu upaya untuk mencapai hasil tersebut. Artinya pendapatan terbentuk bukan atas dasar kontrak penjualan namun dianggap sudah terbentuk seiring dengan berjalannya operasi perusahaan. Pada perusahaan dagang, operasi perusahaan tersebut meliputi kegiatan 
pembelian barang dagangan, transaksi penjualan, dan proses pengumpulan piutang. Sehingga pendapatan baru diakui ketika diterima kas secara utuh atas penjualan kredit dimasa lalu, namun bukan berarti pencatatan pendapatan baru dilaksanakan pada saat kas diterima, hal ini lebih cenderung kepada proses pembentukan pendapatan.

Menurut Baridwan (2010:124) "Piutang dagang adalah piutang yang timbul dari penjualan barang-barang atau jasa-jasa yang dihasilkan perusahaan. Piutang ini merupakan klaim perusahaan atas uang, barang atau jasajasa terhadap pihak-pihak lain, sehingga memungkinkan piutang tidak dapat tertagih secara utuh". Dalam pengakuan rupiah neto (net invoice price) pendapatan neto diakui berdasarkan nilai akhir yang diperoleh, sehingga dalam penjualan secara kredit pendapatan neto adalah pendapatan yang terealisasi tanpa ada piutang yang tidak dapat ditagih atau setelah ada pernyataan nilai piutang yang tidak dapat ditagih, biaya tersebut merupakan biaya yang muncul setelah terjadinya transaksi penjualan, biaya ini dikenal dengan cost purna jual. Perusahaan harus mampu memperkirakan biaya yang mungkin akan dikeluarkan pada saat piutang tidak dapat ditagih, dan tentunya harus dibebankan pada harga jual barang agar tidak mengalami kerugian walaupun menanggung beban tersebut, karena pendapatan merepresentasikan laba yang akan dicapai, dengan demikian penetapan cost purna jual dapat mempengaruhi pendapatan netto.

Berdasarkan hal tersebut, nampak bahwa terdapat korelasi antara pendapatan netto dengan penetapan cost purna jual. Sebagai data awal disajikan gambaran pendapatan netto perusahaan UD M'FAMILY Tasikmalaya:

Tabel 1:

Pendapatan Neto UD M'Family

\begin{tabular}{l|l}
\multicolumn{1}{c|}{ Tahun } & \multicolumn{1}{|c}{ Pendapatan Neto } \\
\hline 2013 & Rp 267.840.000,00 \\
2014 & Rp 482.112.000,00 \\
2015 & Rp 511.056.000,00 \\
2016 & Rp 767.808.000,00 \\
2017 & Rp 848.160.000,00
\end{tabular}

Sumber: Laporan Keuangan UD M'Family

Berdasarkan argumen tersebut, peneliti tertarik untuk meneliti lebih jauh berkaitan dengan indikator-indikator dalam variabel tersebut di atas, dengan judul "Pengaruh Penetapan Cost Purna Jual terhadap Pendapatan Neto Pada UD M'FAMILY Tasikmalaya”.

\section{METODE PENELITIAN}

Penelitian yang akan dilakukan oleh penulis di UD M'FAMILY Tasikmalaya termasuk penelitian kuantitatif dan metode penelitian yang digunakan adalah metode deskriptif.

Menurut Sugiyono (2013:7) bahwa: "Metode kuantitatif dinamakan metode tradisional, karena metode ini sudah cukup lama digunakan sehingga sudah mentradisi sebagai metode untuk penelitian ... metode ini disebut metode kuantitatif karena data penelitian berupa angka-angka dan analisis menggunakan statistik".

Mengenai metode deskriptif dikemukakan oleh Surakhmad (2004:193) bahwa :

Pelaksanaan metode deskriptif tidak hanya dibatasi pada pengumpulan data dan pengelolaan data, tetapi meliputi analisis dan interpretasikan data tentang arti deskriptif, membandingkan persamaan atau perbedaan atau mengukur suatu dimensi tertentu seperti didalam berbagai bentuk komparatif, angka tes, interview dan lainlain, atau mengadakan klasifikasi ataupun mengadakan penilaian, menetapkan standar komparatif, menentukan hubungan dan kedudukan suatu unsur dengan unsur lainnya.

Penelitian yang dilakukan berdasarkan pada laporan keuangan, kartu tagihan dan buku kas yang ada pada UD M'FAMILY Tasikmalaya. Data yang terdapat pada laporan diatas berisi angka-angka sehingga penelitian ini bersifat kuantitatif dan akan menjelaskan peningkatan cost purna jual terhadap pendapatan neto.

Penelitian yang akan dilakukan oleh penulis di UD M'FAMILY Tasikmalaya termasuk penelitian kuantitatif dan metode penelitian yang digunakan adalah metode deskriptif.

Menurut Sugiyono (2013:7) bahwa: "Metode kuantitatif dinamakan metode tradisional, karena metode ini sudah cukup lama digunakan sehingga sudah mentradisi sebagai metode untuk penelitian ... metode ini disebut metode kuantitatif karena data penelitian berupa angka-angka dan analisis menggunakan statistik". 
Mengenai metode deskriptif dikemukakan oleh Surakhmad (2004:193) bahwa:

Pelaksanaan metode deskriptif tidak hanya dibatasi pada pengumpulan data dan pengelolaan data, tetapi meliputi analisis dan interpretasikan data tentang arti deskriptif, membandingkan persamaan atau perbedaan atau mengukur suatu dimensi tertentu seperti didalam berbagai bentuk komparatif, angka tes, interview dan lainlain, atau mengadakan klasifikasi ataupun mengadakan penilaian, menetapkan standar komparatif, menentukan hubungan dan kedudukan suatu unsur dengan unsur lainnya.

Penelitian yang dilakukan berdasarkan pada laporan keuangan, kartu tagihan dan buku kas yang ada pada UD M'FAMILY Tasikmalaya. Data yang terdapat pada laporan diatas berisi angka-angka sehingga penelitian ini bersifat kuantitatif dan akan menjelaskan peningkatan cost purna jual terhadap pendapatan neto.

Penelitian yang dilakukan oleh penulis yaitu dengan menggunakan statistik deskriptif, karena penulis menganalisis data dari laporan keuangan yang dibuat oleh UD M'FAMILY Tasikmalaya. Teknik analisis data yang digunakan dalam penelitian ini menggunakan Uji Koefisien Determinasi.

Pada teknik ini terdiri dari beberapa langkah yaitu uji koefisien korelasi (menggunakan uji koefisien korelasi product moment), uji koefisien deteminasi, dan selanjutnya di uji dengan Uji t. Uji Koefisien Determinasi $(\mathrm{KD})$ bertujuan untuk mengetahui besarnya persentase pengaruh variabel independen $(\mathrm{X})$ terhadap variabel dependen $(\mathrm{Y})$. Langkah-langkahnya sebagai berikut :

a. Analisis data

1. Menganalisis secara deskriptif mengenai cost purna jual pada UD M'FAMILY Tasikmalaya.

2. Menganalisis secara deskriptif mengenai pendapatan neto pada UD M'FAMILY Tasikmalaya.

b. Mengukur tingkat pengaruh cost purna jual terhadap pendapatan neto

1. Uji Koefisien Korelasi Product Moment

Tujuannya untuk mengetahui kekuatan atau keeratan hubungan antara variabel independen $(\mathrm{X})$ dengan variabel dependen (Y). Rumus dari uji koefisien korelasi adalah sebagai berikut :

$$
r=\frac{\mathrm{n} \Sigma \mathrm{XY}-(\Sigma \mathrm{X})(\Sigma \mathrm{Y})}{\sqrt{\left\{\left(\mathrm{n} \Sigma \mathrm{X}^{2}\right)-(\Sigma X)^{2}\right\}} \sqrt{\left\{\left(\mathrm{n} \Sigma \mathrm{Y}^{2}\right)-(\Sigma \mathrm{Y})^{2}\right\}}}
$$

(Arikunto, 2010:327)

Keterangan :

$\mathrm{r}=$ nilai koefisien korelasi

$\mathrm{X}=$ variabel independen yaitu Penetapan

Cost Purna Jual

$\mathrm{Y}=$ variabel dependen yaitu Pendapatan Neto

$\mathrm{n}=$ banyaknya data/sampel/lamanya tahun

Penentuan kuat lemahnya koefisien digunakan batasan-batasan penafsiran sebagi berikut :

Tabel 2:

Pedoman untuk memberikan interpretasi Terhadap Koefisien Korelasi

\begin{tabular}{cc} 
Interval Koefisien & Tingkat Hubungan \\
\hline $0,00-0,199$ & Sangat Rendah \\
$0,20-0,599$ & Rendah \\
$0,40-0,599$ & Sedang \\
$0,60-0,799$ & Kuat \\
$0,80-1,000$ & Sangat Kuat
\end{tabular}

Sumber : (Sugiyono, 2013:231)

2. Analisis Koefisien Determinasi (KD)

Sumbangan variabel $\mathrm{X}$ terhadap variabel $Y$ ditentukan dengan rumus koefisien determinasi, di mana koefisisen ini merupakan kuadrat dari koefisien korelasi PPM yang dikalikan dengan 100\%. Sumbangan tersebut dicari dengan menggunakan rumus sebagai berikut :

$\mathrm{KD}=(\mathrm{r})^{2} \mathrm{X} 100 \%=\ldots \%$

(Riduwan, 2014:76)

Keterangan :

$\mathrm{KD}=$ nilai Koefisien Determinasi

$\mathrm{r}=$ nilai koefisien korelasi

\section{HASIL PENELITIAN DAN \\ PEMBAHASAN \\ Deskripsi Penetapan Cost Purna Jual Pada UD M'FAMILY Tasikmalaya}

Biaya merupakan unsur yang tidak dapat dihindari dalam sebuah usaha, karena biaya merupakan unsur pembentuk atau pencipta pendapatan. Jika dikaji secara mendalam tidak 
mungkin terdapat pendapatan jika biaya tidak dibentuk, karena hakikatnya biaya mendahului pendapatan. Hal tersebut memenuhi konsep upaya dan hasil dimana biaya akan merepresentasikan pendapatan dan lebih lanjutnya akan menggambarkan laba usaha. Maka tidak tepat kiranya jika biaya mengurangi pendapatan, karena biaya tersebut yang menciptakan pendapatan. Biaya yang harus diperhitungkan yakni biaya sebelum penjualan dan biaya setelah penjualan, namun realitanya tidak semua perusahaan memperhatikan biaya yang timbul setelah terjadi penjualan, padahal hal tersebut penting adanya karena dapat mengurangi nilai wajar pada saat pengukuran pendapatan dalam sutau periode bersangkutan.

Berdasarkan hal tersebut dalam setiap usaha tentunya akan menimbulkan biaya yang beragam tergantung dari jenis usaha yang dijalankan. Resiko besar yang dihadapi oleh perusahaan perkreditan yakni adanya piutang yang tidak dapat ditagih. Hal tersebut merupakan salah satu tantangan yang harus mampu dipecahkan oleh seorang pelaku bisnis dalam usaha semacam ini. Untuk menghadapi resiko tersebut perusahaan harus mampu melakukan estimasi biaya yang akan timbul setelah terjadi penjualan karena berkaitan dengan pendapatan neto yang akan diterima oleh perusahaan. Kegiatan estimasi untuk penetapan cost purna jual yang berkaitan dengan biaya piutang tak tertagih, dilaksanakan oleh suatu perusahaan tentunya akan berbeda. Ada perusahaan yang sudah menetapkan atau menaksir diawal periode namun ada pula yang baru mengakui biaya tersebut setelah terjadinya piutang yang benarbenar tidak dapat ditagih.

Pada awal berdiri perusahaan UD M'FAMILY Tasikmalaya beranggapan bahwa biaya pembentuk pendapatan hanya biaya yang timbul sebelum terjadinya penjualan, sehingga biaya setelah penjualan tidak diakui atau tidak diperhitungkan pada awal periode, termasuk biaya piutang tak tertagih. Namun biaya tersebut diakui pada akhir periode yang menyebabkan nilai wajar pendapatan neto tidak sesuai dengan pengakuan pendapatan yang terjadi. Setelah dilakukan analisis ternyata kekurangan nilai wajar pendapatan neto diakibatkan karena biaya yang timbul setelah penjualan yaitu biaya piutang tak tertagih. Biaya ini berkaitan dengan pihak ekstern perusahaan yaitu pelanggan, karena pelanggan yang membantu perusahaan dalam menciptakan pendapatan, sehingga perusahaan yang bergerak dalam sistem pembayaran secara kredit sangat perlu melakukan analisis profitability pelanggan, agar biaya yang timbul dari piutang tak tertagih dapat diminimalisir.

Biaya piutang tak tertagih yang dikeluarkan oleh UD M'FAMILY Tasikmalaya selama lima tahun terakhir mengalami fluktuatif, artinya pada setiap tahunnya tidak terus mengalami peningkatan dan penurunan jumlah biaya piutang tak tertagih yang dikeluarkan. Hal tersebut dipengaruhi oleh likuiditas konsumen dalam melakukan pembayaran utang. Berdasarkan uraian tersebut di atas, maka rincian data biaya piutang tak tertagih pada UD M'FAMILY Tasikmalaya adalah sebagai berikut

Tahun 2013 Perusahaan UD M'FAMILY Tasikmalaya mengeluarkan dana untuk biaya piutang tak tertagih sebesar $\mathrm{Rp} 10.080 .000,00$ dengan penjelasan sebagai berikut :

1. Nilai biaya piutang tak tertagih sebesar kurang lebih 3,5\% dari nilai penjualan neto.

2. Perusahaan belum menerapkan cadangan kerugian piutang pada tahun ini sehingga biaya piutang tak tertagih menjadi pengurang secara langsung pada nilai piutang dan penjualan.

3. Perusahaan baru berdiri sehingga perintis usaha belum melakukan penjaringan konsumen yang memberikan kontribusi optimal dalam proses penciptaan laba.

Tahun 2014 Perusahaan UD M'FAMILY Tasikmalaya mencadangkan dana untuk biaya piutang tak tertagih sebesar Rp 15.552.000,00,00 dengan penjelasan sebagai berikut :

1. Pada tahun ini perusahaan menambah karyawan sebanyak dua orang sehingga terdapat orang-orang baru yang belum ahli dalam menganalisis pelanggan.

2. Perusahaan sudah menerapkan metode penyisihan pada periode ini.

3. Nilai biaya piutang tak tertagih sebesar kurang lebih 3\% dari nilai penjualan, artinya terjadi penurunan prosentase jika dilihat dari perbandingan secara menyeluruh.

Tahun 2015 Perusahaan UD M'FAMILY Tasikmalaya mencadangkan dana untuk biaya piutang tak tertagih sebesar Rp 14.040.000,00 dengan penjelasan sebagai berikut :

1. Pada tahun ini perusahaan mengalami penurunan omset penjualan jika dibandingkan dengan tahun sebelumnya. 
2. Perusahaan sudah menerapkan metode penyisihan atau cadangan pada periode ini.

3. Nilai penetapan biaya piutang tak tertagih sebesar 2,5\% dibandingkan dengan total penjualan.

Tahun 2016 Perusahaan UD M'FAMILY Tasikmalaya mencadangkan dana untuk biaya piutang tak tertagih sebesar Rp 16.512.000,00 dengan penjelasan sebagai berikut :

1. Pada tahun ini perusahaan mengalami kenaikan omset penjualan yang cukup optimal dibandingkan dengan tahun sebelumnya.

2. Perusahaan menerapkan metode penyisihan atau cadangan pada periode ini.

3. Nilai penetapan biaya piutang tak tertagih sebesar $2 \%$ dibandingkan dengan total penjualan.

4. Perusahaan menambah dua orang karyawan.

5. Perusahaan menaikkan persentase penentuan harga jual produk, dari $100 \%$ menjadi $110 \%$ dari harga beli, dengan tujuan untuk mengestimasi atau menutup kerugian akibat biaya piutang tak tertagih.
Tahun 2017 Perusahaan UD M'FAMILY Tasikmalaya mencadangkan dana untuk biaya piutang tak tertagih sebesar Rp 22.800.000,00 dengan penjelasan sebagai berikut :

1. Pada tahun ini perusahaan mengalami penurunan omset penjualan yang dibandingkan dengan tahun sebelumnya.

2. Perusahaan menerapkan metode penyisihan atau cadangan pada periode ini.

3. Nilai penetapan biaya piutang tak tertagih sebesar 2\% dibandingkan dengan total penjualan.

4. Seperti halnya pada tahun sebelumnya, perusahaan menaikkan persentase penentuan harga jual produk, dari $100 \%$ menjadi $110 \%$ dari harga beli, dengan tujuan untuk mengestimasi atau menutup kerugian akibat biaya piutang tak tertagih karena hal tersebut dianggap dapat menaikkan kas bersih yang diterima dari penjualan.

Berdasarkan hasil perhitungan penetapan cost purna jual pada UD M'FAMILY Tasikmalaya tahun 2013 sampai tahun 2017 dapat dilihat dari tabel berikut ini :

Tabel 3:

Penetapan Biaya Piutang Tak Tertagih Periode 2013-2017

\begin{tabular}{l|l|l|l} 
Tahun & $\begin{array}{c}\text { Penetapan Biaya } \\
\text { Piutang tak tertagih }\end{array}$ & $\begin{array}{c}\text { Perubahan } \\
\text { Penetapan Biaya Piutang tak } \\
\text { tertagih dalam persen (\%) }\end{array}$ & $\begin{array}{c}\text { Penurunan dan } \\
\text { Peningkatan } \\
\text { dalam persen (\%) }\end{array}$ \\
\hline 2013 & Rp 10.080.000,00 & 12,76 & - \\
2014 & Rp 15.552.000,00 & 19,69 & 6,93 \\
2015 & Rp 14.040.000,00 & 17,78 & $-1,91$ \\
2016 & Rp 16.512.000,00 & 20,90 & 3,13 \\
2017 & Rp 22.800.000,00 & 28,87 & 7,95 \\
\hline Jumlah & Rp 78.984.000,00 & 100 & 16,1
\end{tabular}

Sumber : Data primer yang diolah tahun 2018

Berdasarkan Tabel 3 bahwa penetapan cost purna jual yang lebih ditujukan pada penetapan biaya piutang tak tertagih yang dicadangkan dan yang direalisasikan oleh Perusahaan UD M'FAMILY Tasikmalaya tahun 2013 sampai tahun 2017 mengalami perubahan pada setiap tahunnya. Penetapan biaya piutang tak tertagih pada tahun 2013 tidak mengalami penetapan atau penaksiran terlebih dahulu karena perusahaan belum memiliki pengalaman melakukan estimasi untuk biaya piutang tak tertagih, namun biaya tersebut tetap dikeluarkan oleh perusahaan sebesar Rp 10.080.000,00 sehingga menjadi pengurang secara langsung terhadap kas bersih dari penjualan. Jika menggunakan persentase nilai ini kurang lebih ada pada angka $12,76 \%$ dari jumlah biaya piutang tak tertagih secara keseluruhan. Pada tahun 2014 perusahaan menetapkan biaya piutang tak tertagih dengan metode estimasi sebesar Rp 15.552.000,00,00 yaitu 19,69\% dari jumlah biaya piutang tak tertagih secara keseluruhan dengan persentase kenaikan 6,93\%. Pada tahun 2015 perusahaan mencadangkan biaya piutang tak tertagih sebesar Rp 14.040.000,00 yaitu sebesar 17,78\% dari jumlah 
biaya piutang tak tertagih secara keseluruhan dengan persentase penurunan $-1,91 \%$. Artinya perusahaan mengalami penurunan penetapan biaya piutang tak tertagih dengan asumsi karena usaha sudah berjalan cukup lama dan omset penjualan menurun. Pada tahun 2016 perusahaan mencadangkan biaya piutang tak tertagih sebesar Rp 16.512.000,00 yaitu 20,90\% dari jumlah biaya piutang tak tertagih secara keseluruhan dan kenaikan nilai biaya piutang tak tertagih sebesar 3,13\%. Artinya perusahaan kembali mengalami peningkatan penetapan biaya piutang tak tertagih. Pada periode ini perusahaan menaikan harapan margin dengan upaya menaikan harga jual, pada awalnya harga jual diambil sebanyak $100 \%$ dari harga beli barang dinaikan menjadi 110\%. Pada tahun 2017 perusahaan meningkatkan taksiran biaya piutang tak tertagih sebesar Rp 22.800.000,00 yaitu sebesar $28,87 \%$ dari jumlah biaya piutang tak tertagih secara keseluruhan dan kenaikan nilai biaya piutang tak tertagih $7,95 \%$. Pada periode ini perusahaan menutup biaya tersebut dengan menaikan harga jual barang seperti pada tahun sebelumnya.

Pada hakikatnya penetapan biaya piutang tak tertagih akan selalu berbanding lurus dengan nilai penjualan, karena persentase yang diambil untuk estimasi biaya tersebut ditetapkan dari besarnya jumlah penjualan. Sehingga biaya piutang tak tertagih akan mengalami kenaikan dan penurunan dilihat dari prosentasenya bukan dari nilainya.

\section{Deskripsi Pendapatan Neto Pada Perusahaan UD M'FAMILY Tasikmalaya}

Pendapatan merupakan bagian penting yang ada di perusahaan, dimana setiap perusahaan mengharapkan jumlah pendapatan yang maksimal sehingga perusahaan akan terus berinovasi dan melakukan riset mengenai produk yang dibutuhkan oleh para konsumen. Pendapatan yang diterima oleh perusahaan UD M'FAMILY Tasikmalaya berasal dari penjualan barang dagangan berupa peralatan rumah tangga dengan sistem door to door atau menggunakan personal selling, dimana karyawan bagian pemasaran secara langsung mendatangi rumah calon konsumen untuk menawarkan produk. Karyawan tersebut juga berlaku sebagai debt collector atau bagian penagihan bagi konsumen yang telah menjadi pelanggan. Perusahaan UD M'FAMILY Tasikmalaya hanya menjual barang dengan sistem kredit, sehingga nilai pendapatan berasal dari penjualan kredit secara utuh. UD M'FAMILY Tasikmalaya melakukan kerjasama dengan beberapa grosir peralatan rumah tangga, dealer, dan perusahaan elektronik lainnya, sehingga supplier yang dimiliki sangat beragam. Dalam transaksi penjualan setiap penjual tidak mengharapkan adanya barang yang dikembalikan (return) karena hal tersebut dapat mengurangi laba yang diharapkan, namun pada realitanya hal tersebut tetap terjadi, namun UD M'FAMILY Tasikmalaya mengatasi resiko tersebut dengan mengembalikannya pada tiap supplier yang bersangkutan jika barang yang dikembalikan konsumen dalam keadaan rusak atau cacat, sehingga perusahaan tidak mengalami kerugian akibat retur dengan angka yang besar. Retur dan potongan harga merupakan unsur pengurang dari pendapatan perusahaan, yang mengakibatkan berkurangnya pendapatan neto yang akan diterima oleh perusahaan seperti halnya pengakuan atas pendapatan yang diakibatkan karena adanya piutang tak tertagih.

Berdasarkan uraian di atas, hasil analisis pendapatan neto Perusahaan UD M'FAMILY Tasikmalaya pada tahun 2013-2017 dapat dilihat pada Tabel 4.2 sebagai berikut :

Tabel 4:

\begin{tabular}{c|c|c|c} 
& \multicolumn{3}{|c}{ Pendapatan Neto Periode 2013-2017 } \\
Tahun & Pendapatan Neto & $\begin{array}{c}\text { Perubahan Pendapatan } \\
\text { Neto dalam Persen (\%) }\end{array}$ & $\begin{array}{c}\text { Penurunan dan } \\
\text { Peningkatan dalam persen } \\
(\%)\end{array}$ \\
\hline 2013 & Rp 267.840.000,00 & 9,31 & - \\
2014 & Rp 482.112.000,00 & 16,76 & 7,45 \\
2015 & Rp 511.056.000,00 & 17,76 & 1,00 \\
2016 & Rp 767.808.000,00 & 26,69 & 8,93 \\
2017 & Rp 848.160.000,00 & 29,48 & 2,79 \\
\hline Jumlah & Rp 2.876.976.000,00 & 100 & 20,17
\end{tabular}

Sumber : Perusahaan UD M'FAMILY Tasikmalaya 2018 
Berdasarkan Tabel 4 di atas, dapat diketahui bahwa jumlah pendapatan neto tertingi dari periode 2012-2017 adalah pada tahun 2017 sebesar Rp 848.160.000,00 dengan persentase peningkatan $2,79 \%$, sedangkan pendapatan neto terendah yang diterima perusahaan terjadi pada tahun 2013 sebesar $\mathrm{Rp}$ 267.840.000,00. Sementara untuk setiap tahunnya mengalami fluktuatif. Pada tahun 2014 pendapatan neto yang diperoleh sebesar Rp 482.112.000,00 yaitu $16,76 \%$ dari jumlah pendapatan neto secara keseluruhan dengan persentase kenaikan sebesar $7,45 \%$, hal ini terjadi karena pada tahun ini perusahaan menambah jumlah karyawan. Pada tahun 2015 pendapatan neto yang diperoleh sebesar Rp 511.056.000,00 yaitu 17,76\% dari jumlah pendapatan neto secara keseluruhan dengan persentase kenaikan 1\%. Pada tahun
2016 pendapatan neto yang diperoleh sebesar Rp $767.808 .000,00$ yaitu $26,69 \%$ dari jumlah pendapatan neto secara keseluruhan dengan persentase kenaikan $8,93 \%$, pada tahun ini perusahaan menambah jumlah karyawan, dan pada tahun 2017 pendapatan neto yang diperoleh sebesar Rp 848.160.000,00 yaitu sebesar $29,48 \%$ dari jumlah pendapatan neto secara keseluruhan dan kenaikan 2,79\%.

\section{Pengukuran Koefisien Korelasi, Pengaruh dan Hipotesis}

1 Uji Koefisien Korelasi Product Moment

Analisis korelasi product moment digunakan untuk mengetahui tingkat kesetaraan hubungan antara penetapan cost purna jual (X) dengan pendapatan neto (Y) adalah sebagai berikut :

Tabel 5:

Perhitungan Korelasi Product Moment

Penetapan cost purna jual (X) Dan Pendapatan Neto (Y)

\begin{tabular}{c|c|c|c|c|c} 
Tahun & $\mathrm{X}$ & $\mathrm{Y}$ & $\mathrm{X}^{2}$ & $\mathrm{Y}^{2}$ & $\mathrm{XY}$ \\
\hline 2013 & 12,76 & 9,31 & 162,32 & 86,68 & 118,80 \\
2014 & 19,69 & 16,76 & 387,7 & 280,9 & 330,00 \\
2015 & 17,78 & 17,76 & 316,13 & 315,42 & 315,77 \\
2016 & 20,9 & 26,69 & 436,81 & 712,36 & 557,82 \\
2017 & 28,87 & 29,48 & 833,48 & 869,07 & 851,09 \\
\hline Jumlah & 100 & 100 & $2.136,94$ & $2.264,43$ & $2.173,46$
\end{tabular}

Sumber : Data primer yang diolah tahun 2018

Berdasarkan tabel di atas untuk mengetahui derajat kerataan hubungan kedua variabel tersebut dapat dihitung dengan menggunakan rumus sebagai berikut :

$\mathrm{r}_{\mathrm{xy}}=\frac{n \sum X Y-\left(\sum X\right)\left(\sum Y\right)}{\sqrt{\left\{\left(n \sum X^{2}\right)-\left(\sum X\right)^{2}\right\}\left\{\left(n \sum Y^{2}\right)-\left(\sum Y\right)^{2}\right\}}}$

$\mathrm{r}_{\mathrm{xy}}=\frac{5 \times 2173,46-(100)(100)}{\left.\sqrt{\left\{\left(5(2,136,94)-(100)^{2}\right.\right.}\right\} \sqrt{\left\{\left(5(2.264,43)-(100)^{2}\right\}\right.}}$

$\mathrm{r}_{\mathrm{xy}}=\frac{10.867,3-10.000}{\sqrt{684,7 \times 1.322,15}}$

$r_{x y}=\frac{867,3}{\sqrt{905.276,105}}$

$r_{\mathrm{xy}}=\frac{867,3}{951,4599}$

$\mathrm{r}_{\mathrm{xy}}=0,911546$

$\mathrm{r}_{\mathrm{xy}}=0,91$ (dibulatkan)
Berdasarkan hasil perhitungan di atas maka nilai $\mathrm{r}$ sebesar 0,91 , hal ini menunjukan bahwa nilai koefisien berada pada tingkat hubungan yang sangat kuat, ditunjukan pada tabel interpretasi koefisien kolerasi pada rentang 0,80 - 1,00. Dengan ini menunjukan arah hubungan antara penetapan cost purna jual dengan pendapatan neto memiliki arah yang sama artinya jika penetapan cost purna jual naik maka pengakuan pendapatan neto pun akan meningkat, dan sebaliknya jika penetapan cost purna jual turun maka pengakuan pendapatan neto pun akan menurun.

\section{Uji Koefisien Determinasi}

Uji koefisien determinasi digunakan untuk mengetahui berapa besar pengaruh penetapan cost purna jual terhadap pendapatan 
neto perusahaan UD M'FAMILY Tasikmalaya maka dapat dihitung dengan menggunakan rumus sebagai berikut:

$$
\mathrm{KD}=\left(\mathrm{r}_{\mathrm{xy}}\right)^{2} \times 100 \%
$$

$\mathrm{KD}=(0,91)^{2} \times 100 \%$

$\mathrm{KD}=0,8281 \times 100 \%$

$\mathrm{KD}=82,81 \%$

Berdasarkan hasil perhitungan di atas dapat diketahui bahwa penetapan cost purna jual berpengaruh terhadap pendapatan neto perusahaan UD M'FAMILY Tasikmalaya dengan nilai Koefisien Determinasi (KD) sebesar $82,81 \%$ sedangkan $17,19 \%$ dipengaruhi faktor lain di luar variabel yang diteliti.

\section{Uji Hipotesis atau Signifikansi (Uji T)}

Untuk menguji signifikansi koefisien determinasi, dapat dihitung dengan menggunakan uji t sebagai berikut :

$$
\mathrm{t}=\frac{r^{2} \sqrt{n-2}}{\sqrt{1-(r)^{2}}}
$$

$\mathrm{t}=\frac{0,91^{2} \sqrt{5-2}}{\sqrt{1-(0,91)^{2}}}$

$\mathrm{t}=\frac{0,8281 \sqrt{3}}{\sqrt{1-0,8281}}$

$\mathrm{t}=\frac{0,8281 \times 1,7320}{\sqrt{0,1719}}$ $\mathrm{t}=\frac{1,4343}{0,41460825}$

$\mathrm{t}=3,45941018$

$\mathrm{t}=3,46$ (dibulatkan)

Untuk menentukan hipotesis diterima atau ditolak, digunakan uji signifikansi sebagai berikut :

a. Jika $t_{\text {hitung }}>t_{\text {tabel }}$, maka hipotesis diterima, artinya ada pengaruh yang signifikan antara variabel $\mathrm{X}$ dengan variabel Y.

b. Jika $t_{\text {hitung }}<t_{\text {tabel }}$, maka hipotesis ditolak, artinya tidak ada pengaruh yang signifikan antara variabel $\mathrm{X}$ dengan variabel $\mathrm{Y}$.

Sehingga dari hasil perhitungan di atas dapat diketahui $t_{\text {hitung }}$ adalah sebesar 3,46 yang kemudian dibandingkan dengan $t_{\text {tabel }}$ dengan kebebasan $(\mathrm{dk})=\mathrm{n}-2=5-2=3$ dan $\alpha=0,05$ maka dapat diperoleh $t_{\text {tabel }}$ 2,353. Dengan demikian $t_{\text {hitung }}$ sebesar 3,46 $>t_{\text {tabel }}$ 2,353, jadi hasil pengujian hipotesis $\mathrm{H}_{\mathrm{a}}$ diterima dan $\mathrm{H}_{\mathrm{o}}$ ditolak dengan demikian bahwa : "Terdapat pengaruh positif dan signifikan antara cost purna jual terhadap pendapatan neto perusahaan UD M'FAMILY Tasikmalaya". Maka hipotesis diterima, di bawah ini digambarkan diagram hasil uji hipotesis :

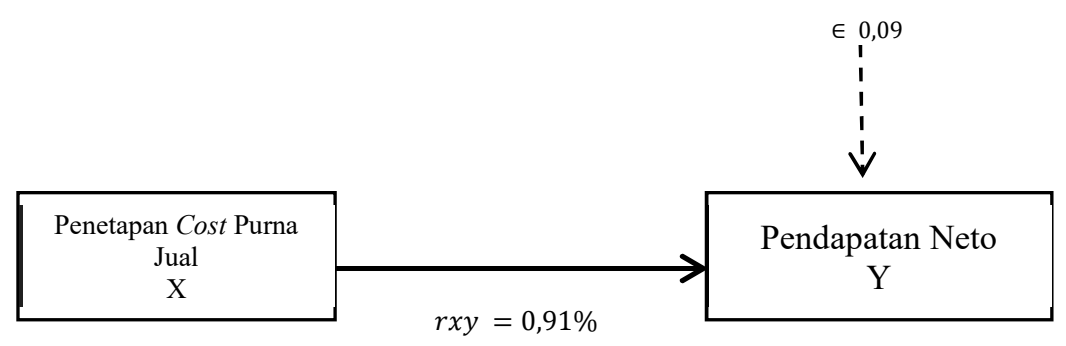

Gambar 1:

Diagram hasil uji hipotesis

Bersandarkan diagram diatas dapat diuraikan bahwa hubungan penetapan cost purna jual dengan pendapatan neto 0,91 (sangat kuat), menunjukan nilai postif serta mempunyai arah yang sama. Artinya jika penetapan cost purna jual naik maka pendapatan neto akan meningkat, dan sebaliknya jika penetapan cost purna jual turun maka pendapatan neto akan menurun. Selanjutnya di bawah ini disajikan tabel rekapitulasi hasil penelitian : 
Tabel 6:

Rekapitulasi Hasil Penelitian

\begin{tabular}{|c|c|c|c|c|c|c|c|}
\hline Variabel & $\sum X$ & $\sum Y$ & Rxy & $\mathrm{KD}$ & $\begin{array}{c}\mathrm{t} \\
\text { hitung }\end{array}$ & $\begin{array}{c}\mathrm{t} \\
\text { tabel }\end{array}$ & Hipotesis \\
\hline $\begin{array}{l}\text { Penetapan cost purna } \\
\text { jual (X) }\end{array}$ & $\begin{array}{l}\text { Rp } 79 \\
\text { (dalam } \\
\text { jutaan ) }\end{array}$ & - & - & - & - & - & - \\
\hline $\begin{array}{l}\text { Pendapatan neto } \\
\text { (Y) }\end{array}$ & - & $\begin{array}{l}\text { Rp } 2.877 \\
\text { (dalam } \\
\text { jutaan) }\end{array}$ & - & - & - & - & - \\
\hline $\begin{array}{l}\text { Penetapan cost purna } \\
\text { jual } \rightarrow(\mathrm{X}) \text { Pendapatan } \\
\text { Neto } \\
\text { (Y) }\end{array}$ & - & - & 0,91 & $\begin{array}{l}82,8 \\
1 \%\end{array}$ & 3,46 & $\begin{array}{l}2,35 \\
3\end{array}$ & $\begin{array}{lr}\mathrm{H}_{\mathrm{a}} & \text { diterima } \\
\text { dan } & \mathrm{H}_{\mathrm{O}} \\
\text { ditolak } & \end{array}$ \\
\hline
\end{tabular}

Berdasarkan Tabel 6 bahwa tingkat hubungan antara penetapan cost purna jual yang dalam hal ini yaitu biaya piutang tak tertagih terhadap pendapatan neto adalah sangat kuat dengan nilai 0,91 dengan persentase $82,81 \%$ sehingga mempunyai nilai positif serta mempunyai arah yang sama, yang artinya jika pentepan cost purna jual naik maka pendapatan neto akan meningkat, dan sebaliknya jika cost purna jual turun maka pendapatan akan menurun. Dari persentase hubungan yang telah dihitung maka berikutnya dapat melakukan pengujian hipotesis dengan uji t, dimana dalam penelitian ini hasil $t_{\text {hitung }}$ adalah 3,46 sedangkan $t_{\text {tabel }}$ sebesar 2,353 jadi $t_{\text {hitung }}>$ $t_{\text {tabel }}$, maka $\mathrm{H}_{\mathrm{a}}$ diterima dan $\mathrm{H}_{\mathrm{o}}$ ditolak dengan demikian bahwa : "Terdapat pengaruh positif dan signifikan antara penetapan cost purna jual terhadap pendapatan neto perusahaan UD M'FAMILY Tasikmalaya'.

\section{PENUTUP}

Berdasarkan hasil penelitian yang telah dilakukan dapat ditarik beberapa simpulan, yaitu sebagai berikut :

1. Penetapan cost purna jual pada UD M'FAMILY Tasikmalaya dalam lima tahun terakhir cenderung berfluktuatif dalam segi persentase cenderung mengalami peningkatan. Hal ini disebabkan karena taksiran penetapan cost purna jual selalu berimbang lurus dengan pendapatan neto.

2. Pendapatan neto pada UD M'FAMILY Tasikmalaya dalam lima tahun terakhir mengalami peningkatan yang signifikan. Hal ini disebabkan karena perusahaan selalu berupaya untuk meningkatkan omset penjualan, dengan upaya menambah karyawan, memilih pelanggan yang berkontribusi terhadap penciptaan laba perusahaan dan lain-lain.

3. Terdapat pengaruh yang positif dan signifikan penetapan cost purna jual terhadap pendapatan neto pada UD M'FAMILY Tasikmalaya, hal ini berarti semakin tepat penetapan cost purna jual maka dapat meningkatkan pendapatan neto.

\section{DAFTAR PUSTAKA}

Baridwan, Zaki. (2004). Intermedite Accounting. Yogyakarta: BPPE Yogyakarta.

Riduwan. (2014). Dasar-dasar Statistika. Bandung: Alfabeta Press.

Sugiyono. (2013). Metode Penelitian Kuantitatif Kualitatif dan $R \& D$. Bandung: Alfabeta, CV.

Surakhmad, Winarno. (2004). Pengantar Penelitian Ilmiah Dasar Metode Teknik. Bandung: Tarsito 
